\title{
Lost and found: the posthumous portrait of Louis Agassiz by Henry Ulke (1876), and their noteworthy relationship
}

\author{
Frederik H. Mollen * (1)
}

\begin{abstract}
Despite today's controversy regarding several aspects of his legacy, Swiss-born Harvard Professor Louis Agassiz (1807-1873) was one of the most eminent scientists of his time. After his death, Washington-based photographer and amateur naturalist, Henry Ulke (1821-1910), honored his 'esteemed friend' which is clear from his personal letter of condolence addressed to Agassiz's eldest son Alexander, and a posthumous portrait (oil on canvas) dated 1876. In 1877, his portrait was purchased by the United States Capitol, but it was not accepted by the Joint Committee on the Library. Thereafter, it soon went missing and remained unnoticed for nearly 150 years, until the same portrait (or at least a second, original version) was brought to auction in 2013 by heirs of the Ulke family. The painting is based on a rare carte-de-visite photograph, which bears the 1876 backstamp of Henry's brother, Julius Ulke (1833-1910). Both the painting and the card, undoubtedly depicting Agassiz, were once mislabeled as General Francis E. Spinner, United States Treasurer (1802-1890), probably by Henry's son, Titus Ulke (1866-1961) or another descendent. The rediscovery of the painting is of major historic and artistic importance. It is now on display in the library of Elasmobranch Research, Belgium.
\end{abstract}

Keywords: Biography, Capitol, Lincoln, Darwin, Wallace, Megatherium Club

\section{Introduction}

Jean Louis Rodolphe Agassiz (1807, Môtier, Switserland-1873, Cambridge, MA, USA) was one of world's most eminent geologists and zoologists of his time. With support and encouragement from his protégées Alexander von Humboldt (1769-1859) and Georges Cuvier (1769-1832), he soon became famous during his early career with his studies on fossil fishes (Agassiz 18331845) and glaciers (Agassiz 1840).

These publications would not have been possible without Agassiz's scientific entrepreneurship that included high-level networking, fundraising, and challenging expeditions into the Swiss Alps and beyond. Yet as a student, Agassiz recruited an illustrator, and later a secretary and

\section{Editorial handling: Daniel Marty.}

*Correspondence: frederik.mollen@gmail.com

Elasmobranch Research, Rehaegenstraat 4, 2820 Bonheiden, Belgium many more, to organize the vast number of projects he initiated. It even included running a printing company to publish his own work, often beautifully illustrated. However, his workaholism came at cost. It put his marriage at stake and, despite his work efforts, significant debts were still impossible to refund (Kaeser 2007; Irmscher 2013).

In 1846, as a 39-year-old married man, and father of three children, Agassiz accepted a well-paid invitation to lecture at the Lowell Institute (Boston, MA), and stayed in the USA thereafter, leaving his domestic problems behind. With 116 lectures at the Lowell Institute alone, his rhetorical gifts, abundant publications, and the foundation of the Museum of Comparative Zoology at Harvard University, Agassiz symbolized American science in the mid-19th century (see, e.g., Smith 1898; Winsor 1991; Irmscher 2013, 2017).

On December 14, 1873, Agassiz died at the age of 66 in his Cambridge home (MA, USA). His legacy was 
celebrated at a Memorial Meeting organized by the California Academy of Sciences, San Francisco (Carr 1874, p. 21): "... Agassiz is not dead. He has gone to sit with Humboldt and Cuvier, with Plato and Aristotle, amongst the stars (...) Agassiz still lives."

Nearly 150 years later, Agassiz's legacy is still very much alive, but his 'star' is not shining as bright as it once was. His study of fossil fishes is still the most important keystone in today's palaeoichthyology. In addition, in times of global warming, Agassiz (1840) reminds us how vast the Swiss glaciers used to look a century and a half ago, saving us from shifting baselines. Nevertheless, Agassiz should also be remembered as the tutor, employer, and scientist who exploited his students, employees, and colleagues, respectively. More than once, Agassiz was accused of committing intellectual theft, even in court, but he was never convicted. Since the publication 'On the Origin of Species' (Darwin 1859), he stubbornly clung to polygenism (i.e., creationism). Above all, Agassiz's legacy is tainted by his contributions to scientific racism. All this should not prevent us from studying and publishing on the life and legacy of Agassiz, but to put things in the right perspective.

In an early, posthumous biography, his former student and later colleague, geologist Marcou (Marcou 1896, vol. 2, p. 251) stated "Agassiz's face has been popularized by many portraits, although not a single good oil portrait of him exists." However, in 1876, not long after Agassiz's death, Henry Ulke (1821-1910), also known as the 'Painter of (American) Presidents' (see e.g., Anonymous 1889, 1910a, b, c, d; Cosentino and Glassie 1983), immortalized his image with a splendid portrait (oil on canvas). Unfortunately, this painting went missing soon after and was forgotten, which explains the hiatus in Marcou's list of portraits. More than a century later, the painting (or at least a second, original version) turned up again at auction. This note reveals the history of the painting(s), and the unreported, yet noteworthy relationship between Agassiz and Ulke.

\section{Materials and methods Institutional abbreviations}

This study involved the consultation of archival material in the following institutions and private collections: Office of the Curator, Architect of the Capitol, Washington DC (AOC); Elasmobranch Research, Belgium (ERB); Institut royal du patrimoine artistique, Brussels (IRPA); Linnean Society of London (LSL); Museum of Comparative Zoology, Ernst Mayr Library, Harvard University, Cambridge (MCZ); Smithsonian Institution, Washington DC (SI); and Ulke Family Collection. The latter collection was not accessible for study, but its curator, Lisa A. Banner (Pratt Institute), provided valuable comments.

\section{Material and repository}

The material examined in this study includes a portrait (oil on canvas) and a carte-de-visite photograph (CDV), depicting Louis Agassiz in half pose length (Figs. 1, 2). The painting is signed in the lower left-hand corner ' $H y$. Ulke 1876', referring to Henry (Heinrich) Ulke (18211910). The CDV bears the 1876 backstamp of the artist's brother, Julius Ulke (1833-1910). Both items are now housed in the ERB collections. The portrait is on display in the ERB library, which specializes in sharks, skates and rays, both recent and fossil, a topic that was very important to Agassiz (see Mollen 2018, 2019).

\section{Origin of the material}

Both items originated from the 'Henry Ulke Collection' (Lisa A. Banner, pers. comm. February 22, 2018). On behalf of its heirs, several items from this collection were put to auction by Swann Auction Galleries (New York, US) on October 10, 2013 (sale 2324, lots 327-355). The portrait and the carte-de-visite were part of the same lot 328. The auction catalog (Swann 2013) includes an introduction to the collection that reads "The following are selections from the Ulke family collection, which has remained intact since his death".

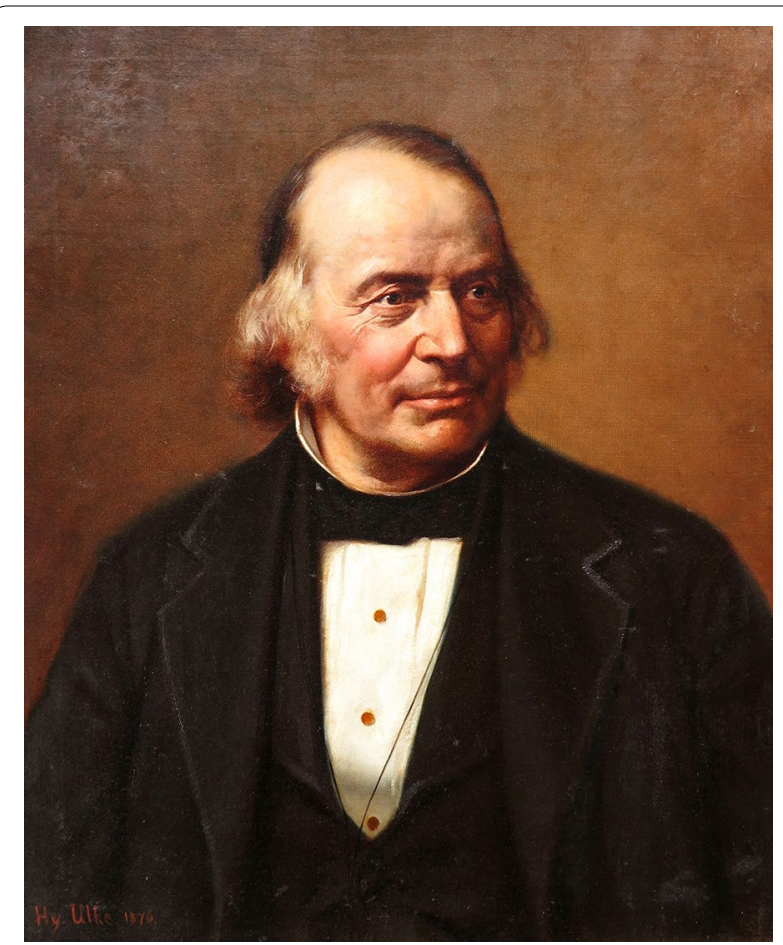

Fig. 1 Posthumous portrait of Louis Agassiz by Henry Ulke (oil on canvas), signed and dated (1876) in lower left-hand corner, after restoration (ex Ulke Family Collection, Swann 2013, sale 2324, lot 328, in part); courtesy of ERB library 


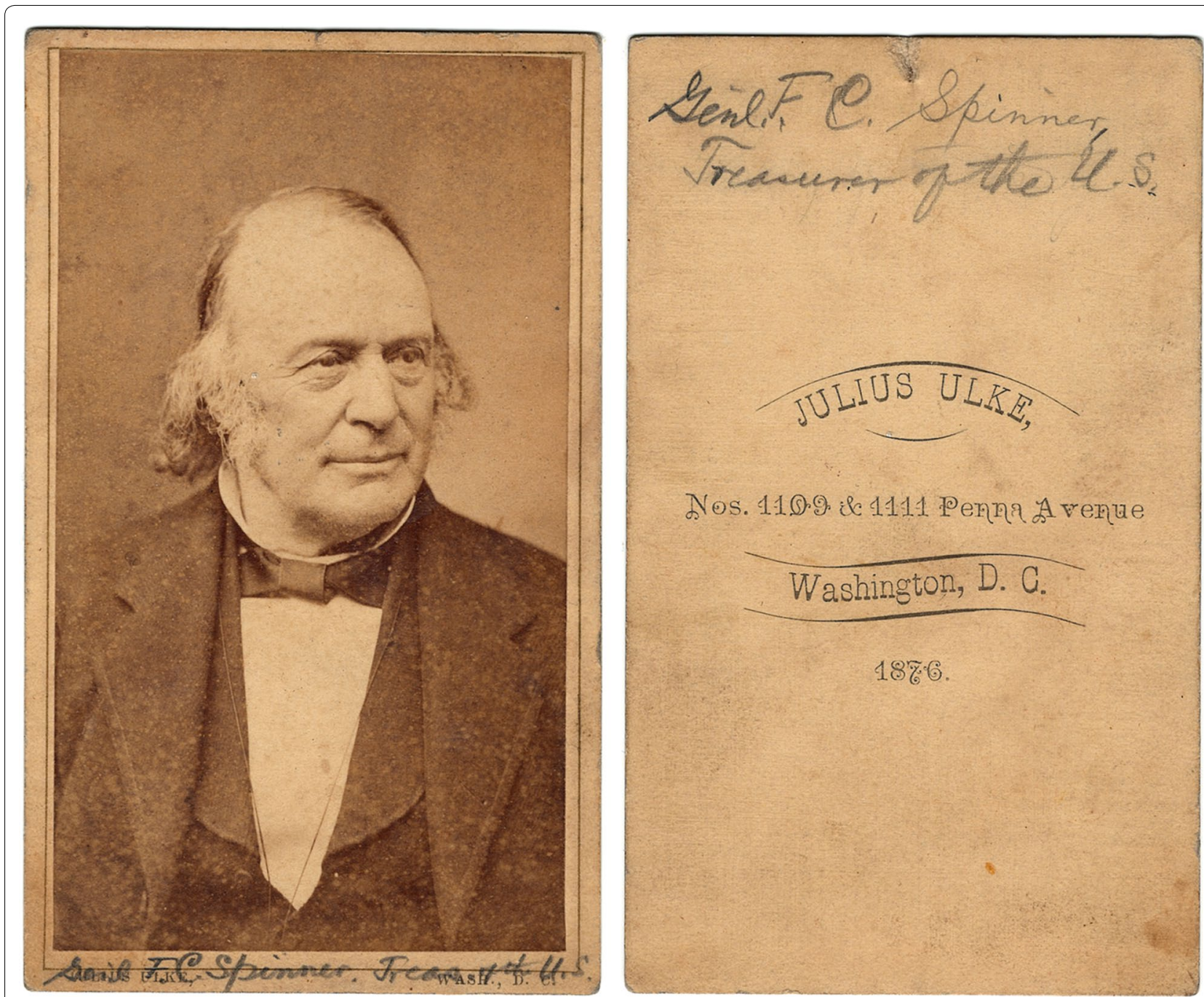

Fig. 2 Carte-de-visite photograph depicting Louis Agassiz, bearing the 1876 backstamp of Julius Ulke (ex Ulke Family Collection, Swann 2013, sale 2324, lot 328, in part); note the card was erroneously identified as 'F.E. Spinner', United States General and Treasurer, probably by Titus Ulke, Henry's eldest son; courtesy of ERB library

\section{Condition of the painting}

The oil painting was unframed $(25 \times 30$ inch.; c. $64 \times 77 \mathrm{~cm}$ ), mounted on original stretchers, showing an obtrusive indentation in the upper left-hand corner, a puncture in the lower right-hand corner, and moderate wear and tear with other small scuffs in general. Upon the advice of the Institut royal du patrimoine artistique (2014), the portrait was subjected to a thorough restoration. For the project's technical details, reference is made to Additional file 1 (Pesesse 2015). After restoration, the painting was framed by the artist Emmanuel Verreydt (Berlaar, Belgium).

\section{Results}

\section{CDV and portrait link}

The carte-de-visite photograph was definitely used as a reference for the portrait, as is suggested in the auction catalog (Swann 2013, see comment to lot 328). It was published here for the first time (Fig. 2), and resembles another well-known photo as published by, for example, Balch and Fay in Boston and New York, respectively (see, e.g., Mollen 2019, Fig. 1), showing Agassiz in a formal half-length pose, looking a little to the left, highlighting the right side of his face. Agassiz is wearing a white shirt, underneath a black spencer and jacket with a collar 
which has a slightly lighter trim or rather a brighter color. His collar tie is fixed (not loose as in many other pictures), and a long necklace is clearly visible. The painting is identical to the carte-de-visite photograph, except for three golden bucklers that were added to the painting, decorating Agassiz's plain white shirt. His shoulders and arms are also more complete on the painting than they are in the photograph.

The 1876 backstamp of Julius Ulke refers to the production of the card, not to the date of photography, nor necessarily to its photographer. The photo was evidently taken a few years earlier, as Agassiz died in December 1873 , and it was probably taken in the photo and portrait studio ran by Julius and Henry Ulke at Pennsylvanian Avenue, Washington DC (first at number 278, later at numbers 1109-1111). The studio enabled the Ulke brothers to photograph many important people from American society, especially those that were based in Washington DC. Subsequently, these photographs also gave Henry Ulke the opportunity to paint many of them who did not have any time to waste simply 'sitting', or even to paint them after their death, as was the case for Agassiz. Albeit in a way of speaking, Irmscher (2013, p. 7) recently stated "One thing is clear: Agassiz will not sit still for his portrait".

\section{Agassiz mistaken for Spinner}

Both the painting and the carte-de-visite photograph, undoubtedly depicting Agassiz, were once erroneously identified as General Francis E. Spinner (1802-1890), US Treasurer. Spinner's name is present on an old handwritten label that is attached to the verso of the stretcher of the painting, and in handwriting on both recto and verso of the carte-de-visite photograph (see Fig. 2). These misidentifications were attributed to Henry's son, Titus Ulke (1866-1961), and a later family member, respectively (Swann 2013), a view followed here. Titus Ulke (1932) presented a biography of his father to the Office of the Curator, Architect of the Capitol (see Additional file 2). It does list more than 20 portraits, including one of ' $\mathrm{L}$. (sic) Spinner', but not of Agassiz. However, it is unlikely that Titus switched both personalities in this unpublished document, too; as the Spinner portrait clearly refers to a painting present at the 'Treasury Building.

\section{A duplicate, or, 'the one and only'?}

In the comments to lot 328, the auction catalog (Swann 2013) stated "The United States Capitol acquired an Agassiz portrait from Ulke in 1877; the present portrait was apparently a duplicate Ulke kept for his own collection".

Indeed, Brown (1903, p. 188, tab. 8, and footnote 4) presented an exhaustive list of paintings in the Capitol, including a painting from Henry Ulke, depicting Agassiz (see also Architect of the Capitol 1998, p. 545). It indicates that it was purchased on "Feb. 7, 1877", and the "Purchase price not given". But, above all, Brown's table states that, at least by the year 1900, Agassiz's portrait was "Not located" anymore, as it still is not to this date (Erik Paff, pers. comm., February 18, 2014). Moreover, an unpublished 'Accession Sheet' for this specific painting (Architect of the Capitol 1975; Additional file 3) reveals that it was "not accepted", but reasons are not provided (see also Architect of the Capitol 1965, p. 398).

The decision to accept any work of art for placement in the United States Capitol rested then, as it does now for joint works, with the Joint Committee on the Library. A number of works of art, that were never accepted by the Committee for public display, have remained in the Capitol. Some are displayed in private offices and some are in storage. Their location is verified during periodic inventories. "The undocumented disappearance of works of art from the Capitol is so rare that we [the Office of the Curator, Architect of the Capitol] cannot suggest a likely fate for this painting." (Erik Paff, pers. comm., February $25,2014)$.

In view of all these facts, a new hypothesis arose. Since it was never accepted, and its price never registered, Agassiz's portrait was perhaps returned to its artist, Henry Ulke. Consequently, the painting auctioned by Swann Galleries on behalf of Ulke's heirs was not a duplicate, but 'the one and only' One way or the other, Agassiz's portrait(s) by Ulke had or have not been seen for 120 years or more. Its rediscovery is of major historic and artistic importance.

\section{Discussion}

\section{Common grounds}

Henry Ulke and Louis Agassiz had more in common than just being the artist and the 'sitter' of the same portrait, respectively. Both were born in Central Europe and spoke German. As far as we know, Agassiz and Ulke did not meet in their early, European careers, but their scientific and artistic work were, respectively, appreciated by Alexander von Humboldt (see Ulke 1932).

Agassiz and Ulke emigrated to the United States in 1846 and 1852, respectively, albeit for different personal reasons (see, e.g., Cronau 1909; Ulke 1932; Kaeser 2007; Irmscher 2013; Lannoo 2018). For Agassiz, it was an important boost to his career, exploring new horizons, leaving marital and financial problems behind, whereas in Ulke's case it was more compelling, due to political motives after being imprisoned during the German revolution that failed in 1848 . Upon their arrival in the US, Louis Agassiz was welcomed with open arms as an 
international celebrity, while Henry Ulke was not. However, later on, the latter would also participate in social activities among the uppermost classes of American society, sharing many mutual friends and contacts.

\section{Lincoln's acquaintance}

During the American Civil War (1861-1865), both Agassiz and Ulke were acquainted with President Abraham Lincoln (1809-1865) in person. A well-documented meeting between Agassiz and Lincoln is that of a conversation at the White House in January 1865 (see, e.g., Lander 2010, p. 248-258). It remains unclear if both men explicitly dealt with topics such as racism and evolution, but their opposing views, outspoken or not, must have caused at least a certain tension in the room (see below). Three months later, on April 14, Henry Ulke and his brother Julius witnessed the murder-attack on Lincoln at Ford's Theatre, and escorted the deadly wounded president to the Petersen House across the street. Here, at the boarding house where the Ulke brothers resided at the time, President Lincoln died the morning after; the famous deathbed picture, taken by the Ulke brothers (see, e.g., Canavan 2015) serves as a reminder.

\section{Born naturalists}

Henry Ulke shared Louis Agassiz's interest in zoology and was an outstanding amateur naturalist, trained by his father as a child. He specialized in Coleoptera (Insecta, Pterygota) when settled in the US (see, e.g., Howard 1900; Ulke 1903; Cronau 1909; Ulke 1932). In April 1858, Ulke was elected as a member of the Academy of Natural Sciences of Philadelphia and became a member of the Entomological Society of Philadelphia the year after. In 1860 , he permanently settled in Washington DC, where he joined the Megatherium Club, a group of amateur naturalists (Fig. 3), founded and run by William Stimpson (1832-1872), one of Agassiz's most gifted pupils (see Mayer 1918; Vasile 2018).

\section{Megatherium Club}

The Club, also known as the 'Stimpsonian', operated from the Smithsonian Institution (Lannoo 2018; Vasile 2018). It was often visited by Louis Agassiz (see, e.g., Herber 1963), to meet with its secretaries Joseph Henry (17971878) and Spencer Fullerton Baird (1823-1887). Like Agassiz, Henry and Baird were also painted by Ulke (see Rathbun 1916), and were among the many mutual contacts Ulke and Agassiz must have had in scientific circles. Louis Agassiz also lectured at the Smithsonian (Herber 1963; Vasile 2018), and albeit unconfirmed, he must have met Henry Ulke in this setting more than once.

After repeated misbehavior of some Club members that lived in the Smithsonian building itself, Stimpson disbanded the club and transformed it into a more formal scientific society, the Potomac Side Naturalist's Club (Mayer 1918; Vasile 2018). One of many incidents was recalled by Oehser (1959, p. 217): "The visiting Louis Agassiz spent many a night in the building as a guest of the Henrys, and there still is circulated the probably not apocryphal story of how, one night, some of the resident "boys" loosened the slats of Agassiz's bed. It is not recorded just what effect this downfall had on the future career of the famous glaciologist."

\section{My esteemed friend}

Except for the painting, we do not know of any document or artifact link between Agassiz and Ulke directly. Nevertheless, on December 15, 1873, the day after Agassiz had died, Ulke (1873) wrote a short letter of condolence to Alexander Agassiz, his eldest son (Fig. 4): "Dear Doctor, It is with the deepest regret that I learned of the untimely demise of your father and my esteemed friend Prof. Agassiz. I scarcely know how to talk of consolation. Accept, dear Doctor, my sincerest condolence under this sad bereavement, and believe me to remain".

Undoubtedly, this letter expresses the personal and close relationship between both men. Consequently, the portrait made by Henry Ulke can be regarded as a posthumous tribute to honor his 'esteemed friend' Louis Agassiz, even though it is unknown if the portrait was commissioned (e.g., by the United States Capitol) or not.

\section{Persona non grata?}

The reason(s) for the non-acceptance of the portrait by the Joint Committee of the Library is (are) not known and one can only speculate. As 'Painter of Presidents', it is very unlikely that Ulke's portrait was rejected because of an issue regarding artistic quality. More likely, the decision was influenced by the subject of the portrait, that is, the personality of Agassiz himself.

Although Louis Agassiz was beloved and praised as one of the greatest of naturalists of his time, his legacy was not without controversy. It is true Agassiz made natural sciences popular, and he was not afraid to get his own hands dirty in the field and supported the scientific education for women. However, Agassiz was also known to exploit many of his assistants and students, and leaned toward polygenism (i.e., creationism), clashing with the upcoming theory of natural selection (i.e., evolution) by Darwin (1859). Moreover, Agassiz was also the proclaimer of scientific racism, although this stain on his career at the time was not yet as big as it is today (see, e.g., Wallis 1995; Hanken 2013; Irmscher 2013, 2017).

One does not speak ill of the dead, especially not shortly after someone's demise. Yet, these problems may have played a significant role in the decision of the 


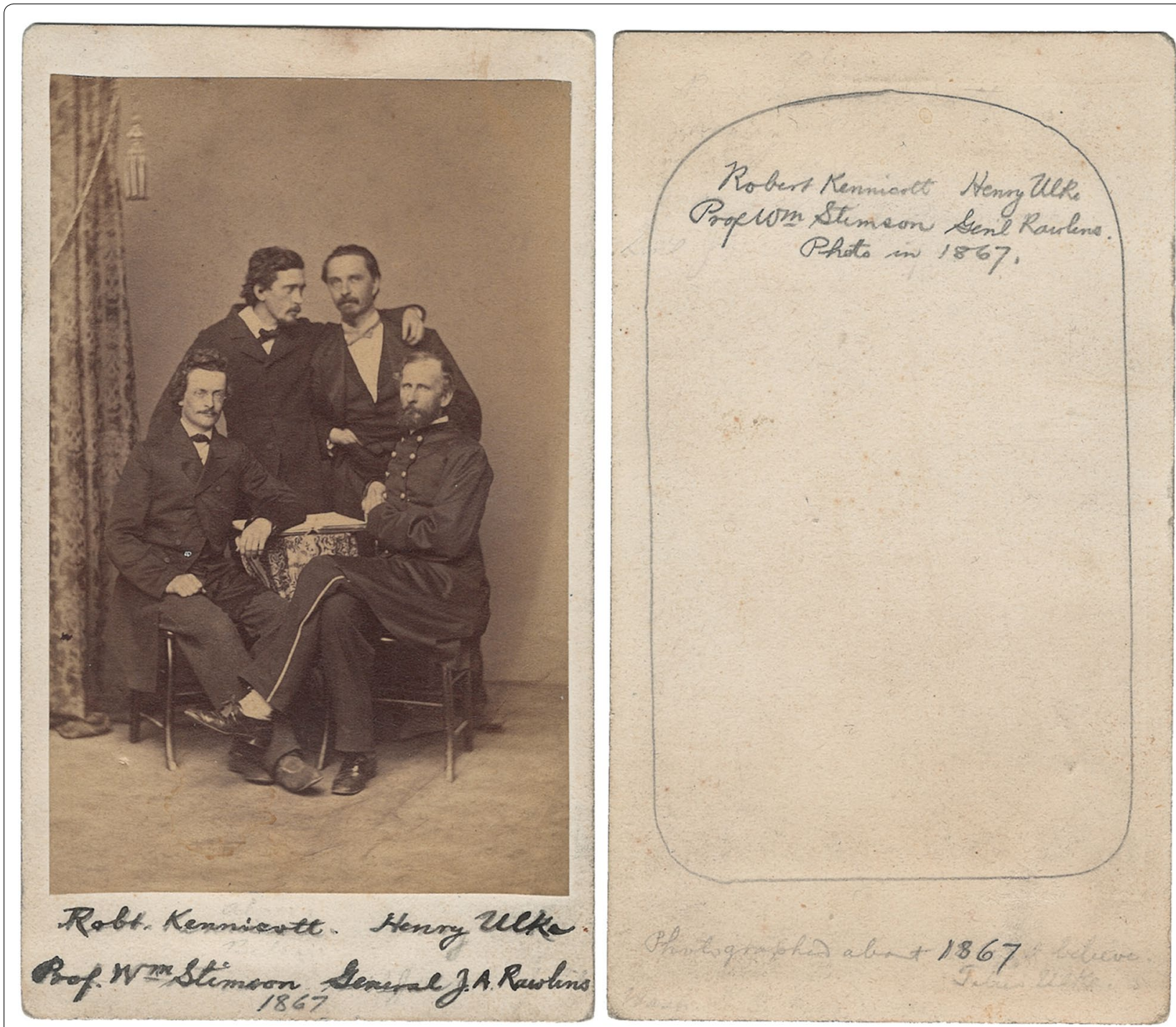

Fig. 3 Megatherium Club members' carte-de-visite (ex Ulke Family Collection, Swann 2013, sale 2324, lot 335), including William Stimpson, founder (bottom left), Henry Ulke (top right), Robert Kennicott (top left) and Henry Bryant (bottom right; for identification see, e.g., Herber 1963, pl. 15); note that in this copy, the latter person was identified as 'General J.A. Rawlins', dated '1867', but obviously taken before as Kennicott died in May 1866; courtesy of ERB library

Committee a few years later. If this is the case, Ulke's feelings might have been hurt, perhaps not so much as an artist, but rather as an admirer and personal friend of Agassiz, reclaiming his portrait that was carefully kept by his descendants until the auction by Swann (2013).

\section{Agassiz vs. Darwin}

Until his death in 1873, Louis Agassiz was one of Charles Darwin's most stubborn opponents (see, e.g., Lander 2010). However, this did not prevent Henry Ulke from naming his second son 'Darwin' Ulke (1876-1939), probably inspired after Charles' surname. On April 19, 1882, Charles Darwin died in his Down House, Kent (UK). Within 4 weeks of time, the Biological Society of Washington organized a Memorial Meeting. Henry Ulke, vice-president of the society at that time, decorated the stage with a portrait of Charles Darwin made from his own hand (Goode et al. 1882, p. 43-44).

So, it seems that Ulke paid tribute both rivals of science, in the same artistic way, but for different reasons. In the case of Agassiz, it was especially for personal reasons, and the general competences and scientific 


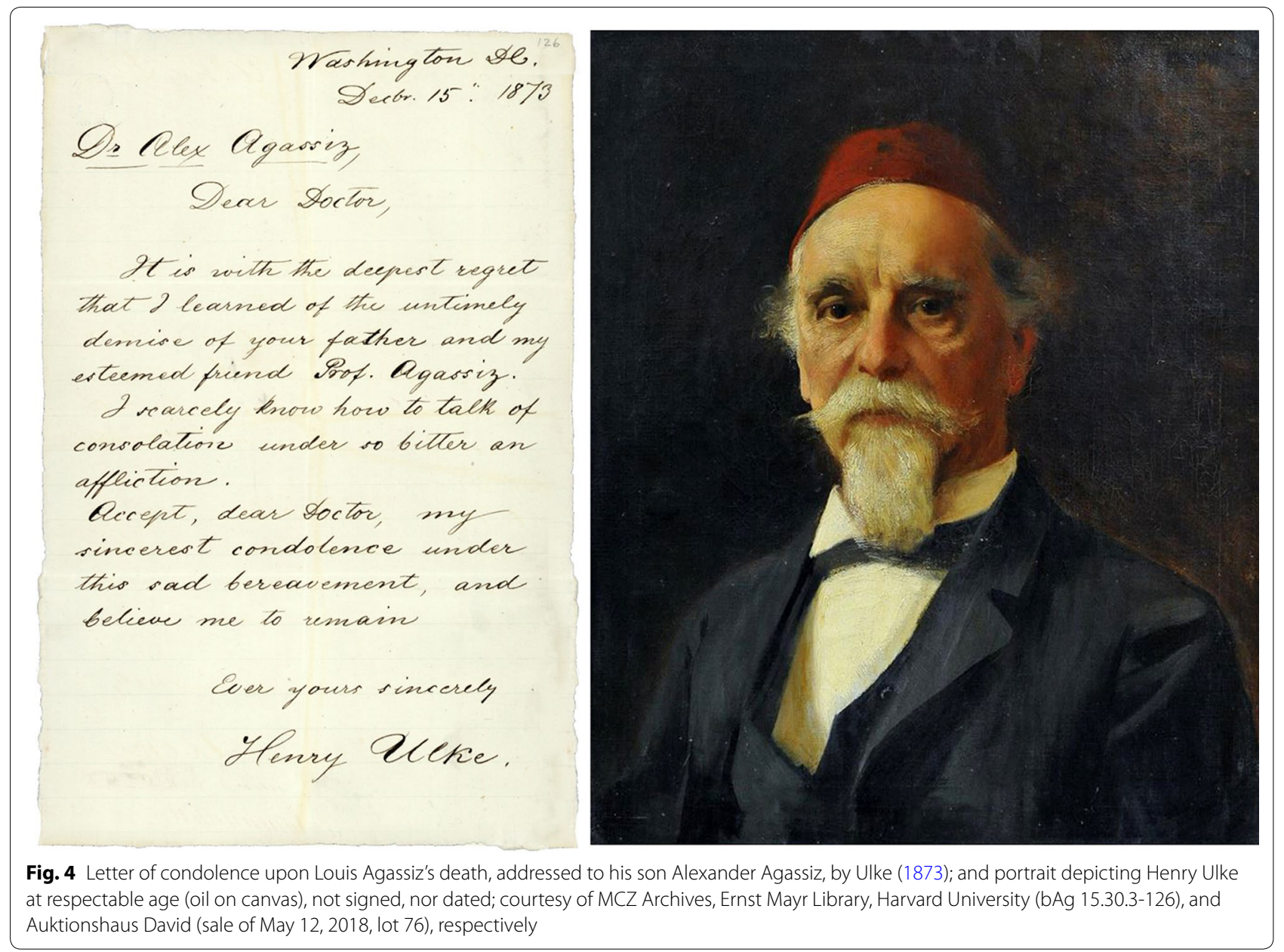

achievement of his 'esteemed friend', rather than his specific views on polygenism and subsequent contributions to scientific racism. In case of Darwin, it was completely the opposite. Ulke was in fact very much interested in Darwin's theory of natural selection. One day, Ulke invited Lester F. Ward to his home to contemplate his fellow vice-president's planned multi-part review of Haeckel's (1874) 'Anthropogenie' or evolution of man (see Ward 1879, 1913). In contrast to Agassiz, Ulke never met, nor communicated with Darwin in person (Rosemary Clarkson, pers. comm. November 4, 2019). Nevertheless, Darwin's coeval Alfred Russel Wallace (1823-1913) gave a lecture tour in the US, "called on Mr Ulke" during one of his final days in Washington DC and noted in his diary (Wallace 18861887; see also Smith and Derr 2013; Fig. 5): "Mr. Ulke's collection of American beetles-fine!".

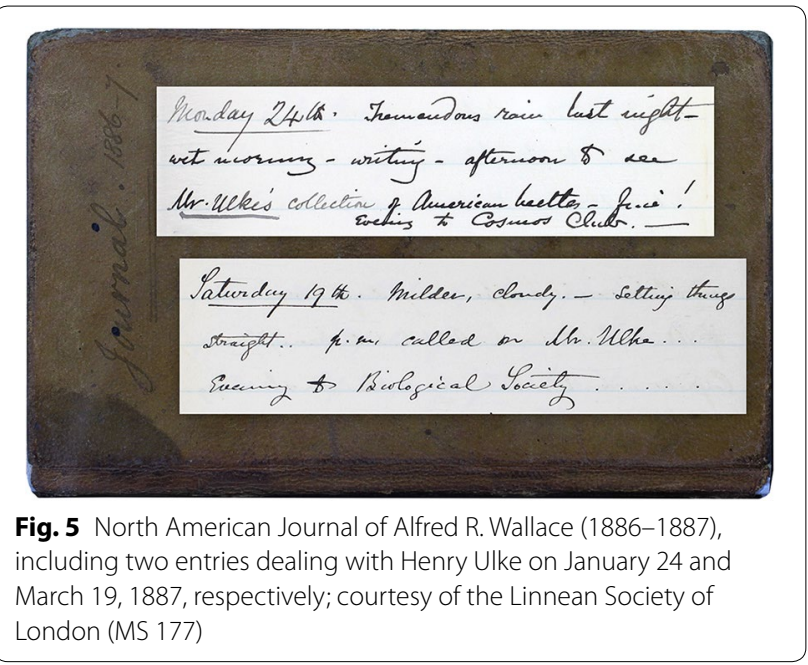

\section{Rest in peace}

On February 17, 1910, Henry Ulke died from a fall in his house at age 89. "He was buried, according to his wish, 
without any religious services whatsoever" (see Ulke 1932, p. 4), a quote that also underlines to his belief in 'evolution', not 'creationism'. His sudden death was mentioned in several newspaper obituaries (see, e.g., Anonymous 1910a, b, c, d), but his richly filled life still merits a decent, modern biography.

\section{Supplementary information}

Supplementary information accompanies this paper at https://doi. org/10.1186/s13358-020-00203-x.

Additional file 1.Restoration project report of Louis Agassiz's portrait by Henry Ulke (Pesesse, 2015); note the condition of the painting (oil on canvas) before and after restoration; courtesy of ERB library.

Additional file 2. Biography of Henry Ulke, by his son Titus Ulke (1932); note a painting of "L. (sic) Spinner" mentioned on top of page 4; courtesy of the Office of the Curator, Architect of the Capitol.

Additional file 3. Accession sheet for a (or the) portrait of Louis Agassiz by Henry Ulke, dated May 27, 1975; note that the portrait was "purchased in 1877 ", but "not accepted"; courtesy of the Office of the Curator, Architect of the Capitol.

\section{Acknowledgements}

I would like to thank Sarah Pesesse (University of Liège) and Emmanuel Verreydt (Berlaar) for the skillful restoration and framing of Agassiz's portrait by Ulke, respectively; Leonard Dewaele (IRSCNB, Brussels) for digitalizing the Ulke records held at the Smithsonian Institution (Washington DC); Eric Paff (Office of the Curator, Architect of the Capitol, Washington DC), Dana Fisher and Robert S. Young (MCZ Archives, Ernst Mayr Library, Harvard University), Rosemary Clarkson (Darwin Correspondence Project, Cambridge University Library), Isabelle Charmantier, Andrea Deneau and Liz McGow (The Linnean Society of London), Alexandra Nelson (Swann Auction Galleries, New York) and David Wernicke (Auctionshaus David, Cologne) for searching archives, scanning documents and/or providing copyright permissions; Lisa A. Banner (curator of the Ulke Family Collection, Pratt Institute, New York) and Christoph Irmscher (Indiana University, Bloomington) for vivid conversations on Ulke and Agassiz, respectively; Michel Agassiz (Collonge-Bellerive) for sending a copy of the exhibition book that was issued upon the bicentenary of Agassiz's birth; the municipal administration of Mont-Vully (comprising Môtier), the Natural History Museum and University of Neuchâtel, the'Fonds Agassiz' (Neuchâtel), and the Grimsel Hospice (Guttannen) for their warm welcome upon our unannounced visit during a Swiss family trip in the summer holidays of 2016, traveling in Agassiz's footsteps; and last but not least, chief editor Daniel Marty (Natural History Museum of Basel) and an anonymous reviewer that provided detailed comments that helped me to improve the manuscript.

\section{Authors' contributions}

The author read and approved the final manuscript.

\section{Funding}

Not applicable.

\section{Availability of data and materials}

Not applicable.

\section{Ethics approval and consent to participate}

Not applicable.

\section{Consent for publication}

Not applicable.

\section{Competing interests}

The author declares that he has no competing interests.
Received: 10 January 2020 Accepted: 28 February 2020

Published online: 26 March 2020

\section{References}

Agassiz, L. (1833-1845). Recherches sur les poissons fossiles. Neuchâtel and Munich: Petitpierre (text), Nicolet and Minsinger (plates).

Agassiz, L. (1840) Études sur les glaciers. Neuchâtel: Soleure (text) and Nicolet (plates).

Anonymous. (1889, April 15). Work of a great artist. Pittsburgh Dispatch, p. 4.

Anonymous. (1910a, February 18). Concussion of the brain ends career of Henry Ulke. The Washington Herald, p. 1.

Anonymous. (1910b, February 19). Henry Ulke dead at 89. The Washington Post, p. 5.

Anonymous. (1910c, February 19). Henry Ulke. The New York Times, P. 11.

Anonymous. (1910d, February 26). Henry Ulke. American Art News, vol. 8, no. 20, p. 4.

Architect of the Capitol. (1965). Compilation of works of art and other objects in the United States Capitol. 88th Congres, 2nd Session, House Document 362, 1-426. Washington, DC: U.S. Government Printing Office.

Architect of the Capitol. (1975). Accession sheet, portrait "Louis Agassiz", artist Henry Ulke (1821-1910). Unpublished. (Archives of the Office of the Curator, Architect of the Capitol; Additionl file 3).

Architect of the Capitol. (1998). Glenn Brown's history of the United States Capitol, annotated edition in commemoration of the bicentennial of the United States Capitol. 108th Congress, 2nd session, House Document 108-240, 1-644. Washington, DC: U.S. Government Printing Office.

Brown, G. (1903). History of the United States Capitol. 56th Congress, 1st Session, House Document 60, 115-255. Washington, DC: U.S. Government Printing Office.

Canavan, K. (2015). Lincoln's final hours., Conspiracy, terror, and the assassination of America's greatest president Lexington: University Press of Kentucky.

Carr, E. S. (1874). Remarks of Robert E. C. Stearns. In Anon. (Ed.), Proceedings of the Agassiz Memorial Meeting, Monday December 22, 1873, at Mercantile Library Hall, 19-21. San Francisco, CA: California Academy of Sciences.

Cosentino, A. J., \& Glassie, H. H. (1983). The capital image., Painters in Washington, 1800-1915 Washington, DC: Smithsonian Institution Press.

Cronau, R. (1909). Drei Jahrhunderte deutschen Lebens in Amerika. Eine Geschichte der deutschen in den Vereinigten Staaten. Berlin: Dietrich Reimer (Ernst Vohsen).

Darwin, C. (1859). On the origin of species by means of natural selection, or the preservation of favoured races in the struggle for life. London: John Murray.

Goode, G. B., Rathbun, R. \& Ward, L. F. (Eds) (1882). Addresses read on the occasion of the Darwin Memorial Meeting, May 12, 1882. Proceedings of the Biological Society of Washington, 1, 1-110.

Haeckel, E. (1874). Anthropogenie oder Entwickelüngsgeschichte des Menschen. Gemeinverständliche wissenschaftliche Vorträge über die Grundzüge der menschlichen Kiemes- und Stammes-Geschichte. Leipzig: Wilhelm Engelmann.

Hanken, J. (2013). A scientist in full. The fruitful, flawed Louis Agassiz. Harvard Magazine, May-June 2013, 22-24.

Herber, E. C. (1963). Correspondence between Spencer Fullerton Baird and Louis Agassiz-two pioneer American naturalists. Washington, DC: Smithsonian Institution

Howard, L. O. (1900). The Ulke collection of Coleoptera. Science, new series, 12(311), 918-920

Institut royal du patrimoine artistique. (2014). Typed letter signed, Livia Depuydt-Elbaum, May 17, 2014. Brussels. (Archives of Elasmobranch Research, Belgium).

Irmscher, C. (2013). Louis Agassiz. Creator of American science. Boston: Houghton Mifflin Haccourt.

Irmscher, C. (2017). Louis Agassiz. Introduction to the study of natural history. Cham: Birkhäuser (Springer International Publishing)

Kaeser, M.-A. (2007). Un savant séducteur, Louis Agassiz (1807-1873), prophète de la science. Vevey: L'Aire.

Lander, J. (2010). Lincoln and Darwin. Shared visions of race, science and religion. Carbondale, IL and Edwardsville, IL: Southern Illinois University Press.

Lannoo, M. J. (2018). This land is your land. The story of field biology in America. Chicago: The University of Chicago Press. 
Marcou, J. (1896). Life, letters, and works of Louis Agassiz. New York: Macmillan and co.

Mayer, A. G. (1918). Biographical memoir of William Stimpson 1832-1872. Biographical Memoirs, 8, 419-433.

Mollen, F. H. (2018). Checklist anxiety: The case for sharks, skates and rays. Journal of Fish Biology, 93(1), 163-164.

Mollen, F. H. (2019). Making Louis Agassiz's wish come true: Combining forces and a new protocol for collecting comparative skeletal material of sharks, skates and rays, as a comment and an addition to 'The need of providing tooth morphology in descriptions of extant elasmobranch species' by Guinot et al. (2018). Zootaxa, 4571(2), 295-300.

Oehser, P. H. (1959). The role of the Smithsonian Institution in early American geology. Journal of the Washington Academy of Sciences, 49(7), 215-219.

Pesesse, S. (2015). Dossier de restauration, portrait d'Agassiz par Henry Ulke, 1876. Unpublished. (Archives of Elasmobranch Research, Belgium; Additional file 1).

Rathbun, R. (1916). The national gallery of art, department of fine arts of the National Museum. Bulletin of the United States National Museum, 70, $1-189$.

Smith, H. K. (1898). The history of the Lowell Institute. Boston: Lamson, Wolffe and Company.

Smith, C. H., \& Derr, M. (Eds.). (2013). Alfred Russel Wallace's 1886-1887 travel diary. The North American lecture tour. Manchester: Siri Sci Press.

Swann, G. (2013). Printed \& manuscript Americana [Auction Catalogue], Public Auction Sale 2324, October 10, 2013. New York: Swann Auction Galleries.

Ulke, H. (1873) Letter of condolence to Alexander Agassiz (Washington DC, December 15, 1873). ALS bAg 15.30.3-126. (MCZ Archives, Ernst Mayr Library, Harvard University).
Ulke, H. (1903). A list of the beetles of the district of Columbia. Proceedings of the United States National Museum, 25(1275), 1-57.

Ulke, T. (1932). Biography of Henry Ulke. Unpublished. (Archives of the Office of the Curator, Architect of the Capitol; Additional file 2).

Vasile, R. S. (2018). William Stimpson and the golden age of American natural history. DeKalb: Northern Illinois University Press.

Wallace, A. R. (1886-1887). North American Journal. MS 177, http://linne an-online.org/54016/. Accessed November 22, 2019 (Archives of the Linnean Society of London).

Wallis, B. (1995). Black bodies, white science: Louis Agassiz's slave daguerreotyes. American Art, 9(2), 38-61.

Ward, L. F. (1879). Haeckel's Genesis of Man or history of the development of the human race being a review of his "Anthropogenie", and embracing a summary exposition of his views and of those of the advanced German school of science. Philadelphia: Edward Stern and co.

Ward, L. F. (1913). Glimpses of the cosmos, comprising his minor contributions now republished, together with biographical and historical sketches of all his writings., Period, 1875-1882. Age, 34-40 New York: G. P. Putnam's Sons, Knickerbocker Press.

Winsor, M. P. (1991). Reading the shape of nature. Comparative zoology at the Agassiz Museum. Chicago: University of Chicago Press.

\section{Publisher's Note}

Springer Nature remains neutral with regard to jurisdictional claims in published maps and institutional affiliations.

\section{Submit your manuscript to a SpringerOpen ${ }^{\odot}$ journal and benefit from:}

- Convenient online submission

- Rigorous peer review

- Open access: articles freely available online

- High visibility within the field

- Retaining the copyright to your article

Submit your next manuscript at $\boldsymbol{\nabla}$ springeropen.com 